\title{
Bruk av akuttmedisinsk ultralyd ved evaluering av pasienter med mistenkt COVID-19 infeksjon i akuttmottaket
}

Lars Petter Bjørnsen, MD, PhD, Overlege

1. amanuensis NTNU, Akutten, Klinikk for

akutt- og mottaksmedisin, St. Olavs hospital, Trondheim

I lys av den pågående COVID-19 epidemien i Norge er det avgjørende å utvikle og benytte kliniske verktøy for å vurdere og risikostratifisere pasienter med mistenkt koronasmitte $\mathbf{i}$ akuttmottaket. Ultralyd har vist seg å være et slikt verktøy.

Den akuttmedisinske ultralyden er et supplement til den akutte kliniske undersøkelsen av pasienter. Fokusert akuttmedisinsk ultralyd eller point-of-care ultrasound (PoCUS), som det også kalles, har ikke som mål å erstatte eller overta for en grundig og systematisk ultrasonografisk undersøkelse, men søker primært understøtte eller avkrefte differensialdiagnostiske betraktninger $\mathrm{i}$ den initiale vurderingen av en akutt syk eller skadet pasient.

Det har vært økt fokus på diagnostisk bruk av ultralyd ved virale pneumonier, inkl. COVID-19, og dette har vist seg å ha god nytteverdi [1, 2]. Akuttleger utfordres i møte med disse pasientene tidlig i forløpet i akuttmottaket og det er avgjørende at legene har verktøy til hjelp i primærvurde- ringen. Bruk av ultralyd vil kunne bidra til rask avdekking av lungeforandringer forenelig med økende alvorlighetsgrad hos pasienter med COVID-19 sykdom [3]. Studier viser at ultralyd har en meget høy sensitivitet for interstitielle og alveolære lungesykdommer, samt at funnene korrelerer med histopatologi og CT bilder.

Det er nå igangsatt en multisenterstudie i Norge hvor man ser på effekten av ultralydbruk i evalueringen av akutt syke pasienter med mistanke om koronasmitte. Ultralyddiagnostikk av potensielt koronasmittede pasienter gjennomføres ved en rekke akuttmottak. Data vil bli analysert med tanke på om ultralyddiagnostikk kan hjelpe i risikostratifisering og logistikk av pasienter med mistanke om COVID-19 smitte. Ultralyd vil kunne benyttes for avklaring av pasienter i forhold til hjemsendelse, vurdering av alvorlighetsgrad og vurdering av effekt på behandling og tiltak. Samtidig vil bruk av ultralyddiagnostikk i akuttmottaket ved å redusere transport av smittede pasienter til annen bildediagnostikk og dermed minske smitteeksponering av annet helsepersonell [3].

Prosjektet er en multisenterstudie hvor en rekke akuttmottaket ved både lokalsykehus og universitetssykehus deltar og ultralydfunn fra pasientenes lunger graderes etter et skåringssystem og sammenstilles med annen klinisk pasientinformasjon [4]. Prosjektet er planlagt fram til slutten av 2021 og det er knyttet stor spenning til resultatene.

\section{References}

[1] Huang Y, Wang S, Liu Y et al. A Preliminary Study on the Ultrasonic Manifestations of Peripulmonary Lesions of Non-Critical Novel Coronavirus Pneumonia (COVID-19) (February 26, 2020). Available at SSRN: https://ssrn.com/ abstract $=3544750$ or http://dx.doi.org/ $10.2139 /$ ssrn. 3544750

[2] Moro F, Buonsenso D, Moruzzi MC et al. How to perform lung ultrasound in pregnant women with suspected COVID-19 infection. Ultrasound Obstet Gynecol 2020; 55: 593-598. doi:10.1002/uog.22028

[3] Soldati G, Smargiassi A, Inchingolo R et al. Is there a role for lung ultrasound during the COVID-19 pandemic? J Ultrasound Med 2020. doi:10.1002/jum. 15284

[4] Soldati G, Smargiassi A, Inchingolo R et al. Proposal for international standardization of the use of lung ultrasound for COVID-19 patients; a simple, quantitative, reproducible method. J Ultrasound Med 2020. doi:10.1002/ jum. 15285 